INFO ARTIKEL

Riwayat Artikel:

Diterima : :01 Januari 2020

Disetujui : 02 Februari 2020

\title{
GEOGRAFI
}

\section{PENDUGAAN CADANGAN KARBON PERMUKAAN HUTAN DI PULAU BATAM MENGGUNAKAN DATA PENGINDERAAN JAUH}

\author{
Arini Dewi Lestari Situmorang ${ }^{1}$, Wenang Anurogo², Muhammad Zainuddin Lubis ${ }^{3}$ \\ ${ }^{1-3}$ Program Studi Teknik Geomatika Politeknik Negeri Batam Batam Center \\ ( $\Xi)$ arinidewilestari2@gmail.com ${ }^{1}$, wenang@polibatam.ac.id ${ }^{2}$
}

\begin{abstract}
ABSTRAK
Dampak negatif dari pemanasan global yang disebabkan oleh emisi gas rumah kaca adalah salah satu masalah yang dihadapi dunia khususnya Indonesia. Emisi karbon sebagai penyumbang terbesar bagi emisi gas rumah kaca perlu dipantau dan dialamatkan. Hutan sebagai ekosistem yang memiliki vegetasi dalam jumlah besar dan benda hidup lainnya memiliki peranan penting dalam menyerap dan menyimpan karbon. Memperkirakan jumlah stok karbon pada penelitian ini diawali dengan penghitungan jumlah biomassa permukaan di hutan Pulau Batam menggunakan persamaan Brown (1997), hal ini didasarkan pada ketentuan SNI 7724:2011 bahwa 47\% biomassa adalah karbon. Teknologi penginderaan jauh yang terus bertambah dapat digunakan untuk memperkirakan jumlah stok karbon permukaan yang tersimpan di hutan Pulau Batam. Data penginderaan jauh yang digunakan dalam penelitian ini adalah data gambar SPOT 5 dengan resolusi spasial 10 meter. Data ini kemudian diproses menggunakan indeks MSAVI transformasi, hasil dari nilai indeks transformasi kemudian diuji regresi dan korelasi dengan hasil konversi karbon dari Perhitungan jumlah biomassa berdasarkan data lapangan. Hasil penelitian ini adalah perkiraan jumlah stok karbon permukaan yang dapat ditampung oleh hutan Pulau Batam adalah 6189944, 681939 gram atau 6189944, 681939 x 10-4 ton C/ha dengan tingkat kesalahan 4, 731672893.
\end{abstract}

Kata Kunci: Brown Allometric, stok karbon, hutan, data remote sensing

\section{PENDAHULUAN}

Perubahan iklim global menjadi salah satu masalah yang cukup menarik perhatian dunia termasuk di Indonesia. Peningkatan iklim berupa pemanasan global diakibatkan oleh meningkatnya emisi gas rumah kaca yang berasal dari pembakaran fosil, pembakaran sampah, dekomposisi dan lain lain. Gas CO2 memiliki ranking teratas (> 80\%) dalam berkontribusi terhadap emisi gas rumah kaca (Akbar, A. 2012). Karbon sebagai penyumbang gas rumah kaca tertinggi di atmosfer, perlu dipantau dan diatasi guna mengurangi emisi karbon di kelangsungan kehidupan bumi saat ini dan dimasa yang akan datang.

Hutan merupakan ekosistem yang menyerap dan menyimpan karbon dalam jumlah besar.
Negara-negara industri yang sudah lebih lama dan banyak mengemisikan GRK mempunyai tanggungjawab menurunkan emisi GRK. Kewajiban ini disepakati dalam sebuah perjanjian internasional Konvensi Perubahan Iklim yang tertuang dalam Protokol, yaitu Protokol Kyoto. Protokol ini juga mengatur tatacara penurunan emisi termasuk kegiatan yang dilakukan di negara lain yang dikenal dengan nama Mekanisme Pembangunan Bersih atau Clean Development Mechanism (CDM) (Samiaji, T. 2010; dan Agus, F. 2004).

Melalui mekanisme CDM inilah negara berkembang seperti Indonesia dapat menjual karbon yang mampu diserap dan disimpan oleh hutan yang dimiliki ke negara maju (sink program). Pasca 
Kyoto Protocol akan diberlakukan mekanisme perdagangan karbon yang disebut Reducing Emissions from Deforestation and Degradation (REDD) yang pada Conference of Parties (COP-13) di bawah Mekanisme Kerja Konvensi PBB tentang Perubahan Iklim (UNFCCC) di Bali bulan Desember 2007 sudah dibicarakan.

REDD merupakan peluang konservasi karbon pada lahan gambut di Indonesia. Harga kredit karbon yang dunia dewasa ini berkisar antara $\$ 4$ sampai \$18 per ton $\mathrm{CO} 2$. Harga yang diberlakukan untuk REDD kemungkinan sekitar \$5 per ton CO (Wicaksono, at all 2016). Indonesia sangat berpotensi menjadi negara penyerap emisi karbon karena Indonesia mempunyai hutan tropis yang luas bahkan potensi tersebut dapat lebih ditingkatkan dengan upaya penanaman dan rehabilitasi hutan yang telah rusak yang tersebar luas. Dengan memanfaatkan teknologi penginderaan jauh, pendugaan jumlah cadangan karbon menjadi lebih efektif dari segi waktu, tenaga dan biaya terutama pada wilayah dengan vegetasi yang cukup luas seperti hutan.

\section{METODOLOGI PENELITIAN}

Lokasi penelitian dilakukan di daerah Pulau Batam, Provinsi Kepulauan Riau pada koordinat $01^{\circ} 08^{\prime} \mathrm{LU} 104^{\circ}$ 00' BT. Wilayah Pulau Batam yang tidak terlalu luas berpengaruh dengan sedikitnya wilayah hutan seiring dengan terus terjadinya pembukaan lahan. Penelitian pendugaan cadangan karbon ini dilakukan selama 4 Bulan diawali dengan pengolahan data citra SPOT 5, pengambilan data survey vegetasi lapangan berdasarkan hasil pengolahan citra, selanjutnya dilakukan perhitungan biomassa berdasarkan data survey vegetasi di lapangan yang biasanya menggunakan persamaan allometrik, penyusunan dan penentuan model penduga biomassa, dan akhirnya dilakukan verifikasi model pendugaa karbon. Berikut adalah peta lokasi yang digambarkan pada Gambar 1.

Pada penelitian ini, data penginderaan jauh yang digunakan adalah salah satu data citra spesifikasi sedang dengan resolusi spasial sebesar 10 Meter. Dengan menggunakan komposit 321 pada data citra SPOT 5 sebelum dilakukan pengolahan lebih lanjut perlu dilakukan koreksi radiometrik dan koreksi geometric pada data citra SPOT 5. Pendugaan biomassa menggunakan penginderaan jauh merupakan metode yang cukup efektif dalam segi waktu dan biaya. Dimana nilai indeks vegetasi yang didapatkan dari hasil pengolahan data citra dengan transformasi Modified Soil Adjusted Vegtation Index (MSAVI).

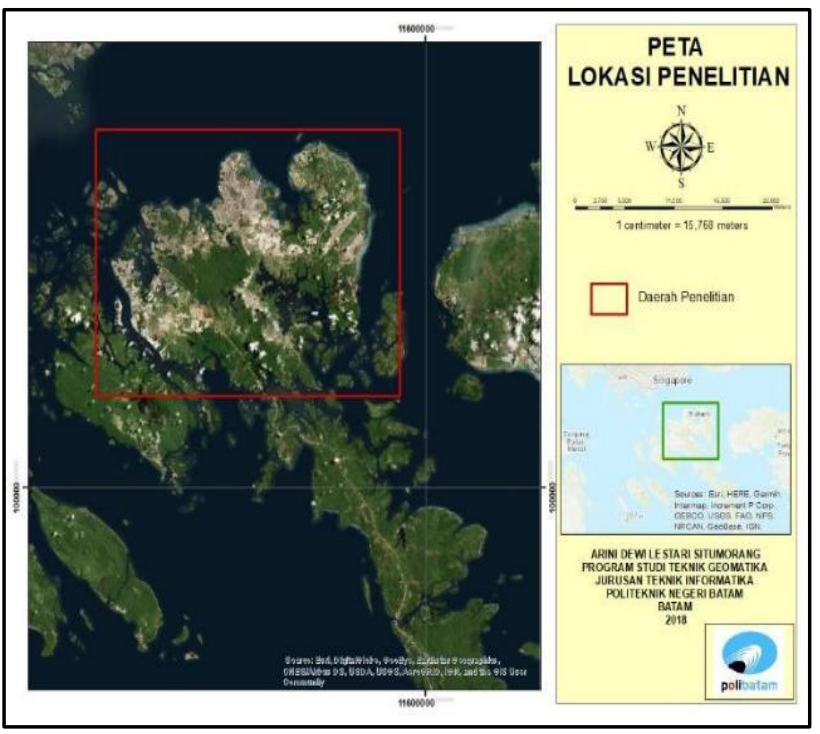

Gambar 1. Peta Lokasi Penelitian

MSAVI merupakan suatu transformasi yang dikembangkan dari transformasi Normalized Difference Vegetation Index (NDVI) untuk meminimalkan pengaruh pantulan tanah pada transformasi NDVI (Anurogo, W., \& Murti, S, 2013). Formula transformasi MSAVI adalah sebagai berikut:

$$
M S A V I=\frac{\left\{2(N I R)+1-\sqrt{\{2(N I R)+1\}^{2}-8\{(N I R)-R e d}\right.}{2}
$$

Nilai indeks transformasi yang didapatkan dari transformasi MSAVI yang dilakukan akan digunakan sebagai interpretasi untuk mengetahui sebaran dan nilai biomassa di lapangan. Nilai transformasi ini juga akan dianalisis hubungan regresinya terhadap diameter kanopi dan terhadap nilai hasil konversi karbon dari perhitungan biomassa berdasarkan data yang diambil dilapangan.

Biomassa sangat berperan dalam proses siklus karbon. Jumlah cadangan karbon yang tersimpan dalam sekumpulan vegetasi dapat diketahuai dengan menghitung jumlah biomassanya, sesuai dengan ketentuan SNI 7724:2011 bahwa 47\% dari biomassa adalah karbon (Indonesia, S. N, 2011). 
Persamaan Brown (1997) merupakan persamaan yang umum dan sering digunakan pada penelitian penelitian biomassa (Brown, S, 1997; dan Windarni, C., Setiawan, A., \& Rusita, R. 2018). Persamaan ini digunakan untuk memprediksi biomassa pada penutup lahan bersifat alami seperti hutan dan semak belukar. Allometrik Brown yang digunakan pada penelitian ini merupakan allometrik untuk menghitung biomassa tegakan hutan berdasarkan bagian - bagian dari tegakan tersebut (batang, ranting dan daun). Berikut adalah persamaan allometrik yang digunakan pada penelitian ini:

a) Allometrik perhitungan biomassa pada bagian batang tegakan:

$$
\mathrm{B}=0,0912 . \mathrm{D}^{2,2}
$$

b) Allometrik perhitungan biomassa pada bagian ranting tegakan:

$$
\mathrm{B}=0,0162 . \mathrm{D}^{2,43}
$$

c) Allometrik perhitungan biomassa pada bagian daun tegakan:

$$
\mathrm{B}=0,269 . \mathrm{D}^{1,7828}
$$

Pengambilan data lapangan dilakukan pada objek atas permukaan yaitu pada diameter kanopi dan diameter batang pohin sampel yang telah ditentukan. Jumlah sampel pada penelitian ini adalah 37 titik sampel dengan pengambilan sampel yang digunakan adalah Purposive Sampling. Pembuatan model juga dilakukan untuk mengetahui seberapa besar hubungan data citra SPOT 5 sebagai data penginderaan jauh yang digunakan terhadap data lapangan menggunakan persamaan regresi.

Dalam mengetahui tingkat kepercayaan data hasil penelitia ini dilakukan perhitungan Root Mean Square Error (RMSE) yang bertujuan untuk membuktikan perhitungan hasil perhitungan yang telah dilakukan apakah sudah akurat atau masih terdapat kesalahan dalam proses perhitungan dan berapa besar error dari data statistik yang digunakan. Diagram Alir penelitian digambarkan pada Gambar 2.

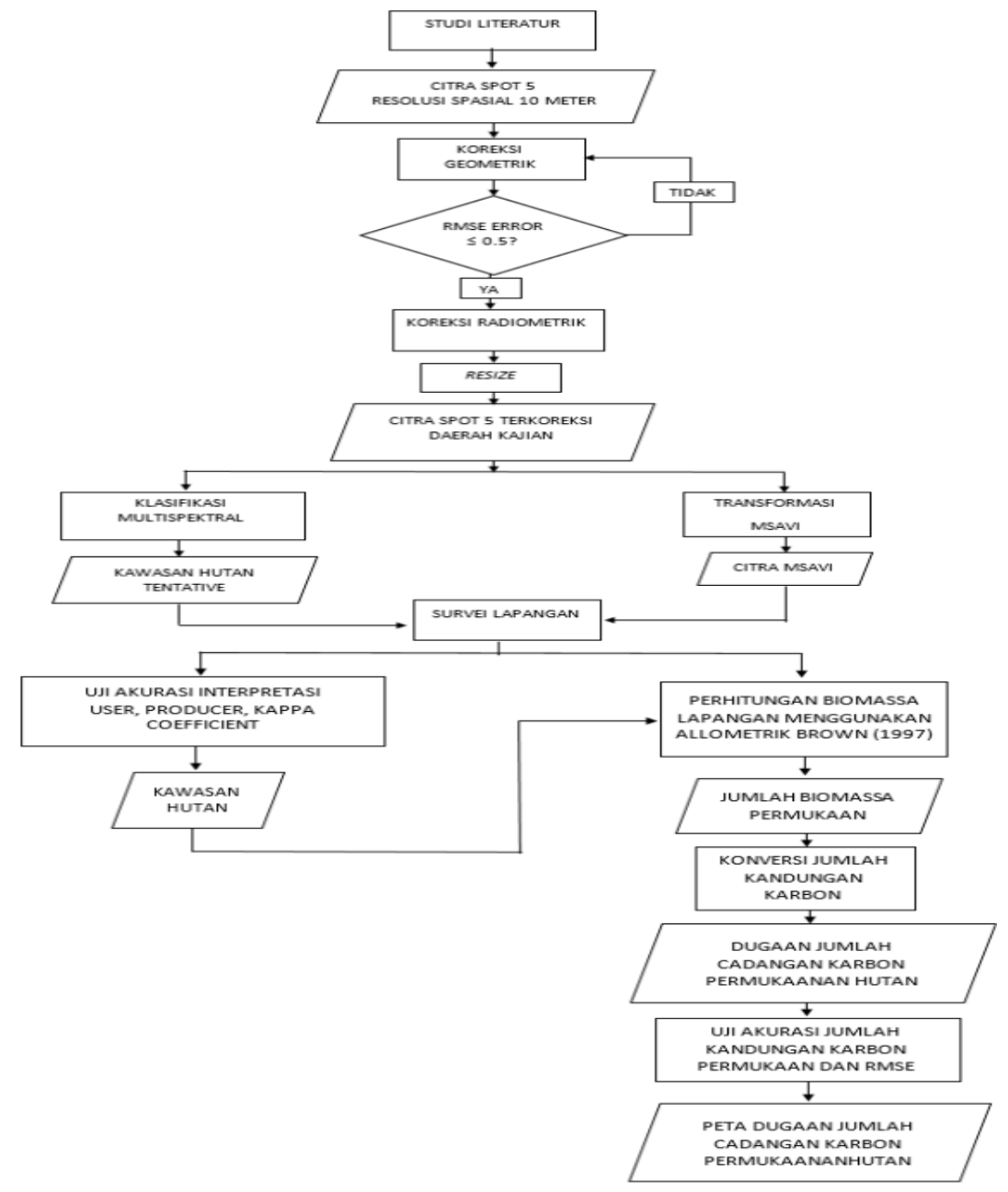

Gambar 2. Diagram Alir Penelitian 


\section{HASIL DAN PEMBAHASAN}

Tahap awal yang perlu dilakukan dalam pengolahan data citra pada penelitan ini adalah koreksi geometrik dan radiometrik. Hal ini bertujuan untuk meningkatkan kualitas visual citra dan keakurasian informasi yang didapatkan dari data citra SPOT 5 sebagai data penginderaan jauh yang digunakan dengan resolusi spasial citra SPOT 5 yang digunakan pada penelitian ini adalah sebesar 10 meter. Resolusi ini lebih jelas dapat dilihat pada gambar 3.

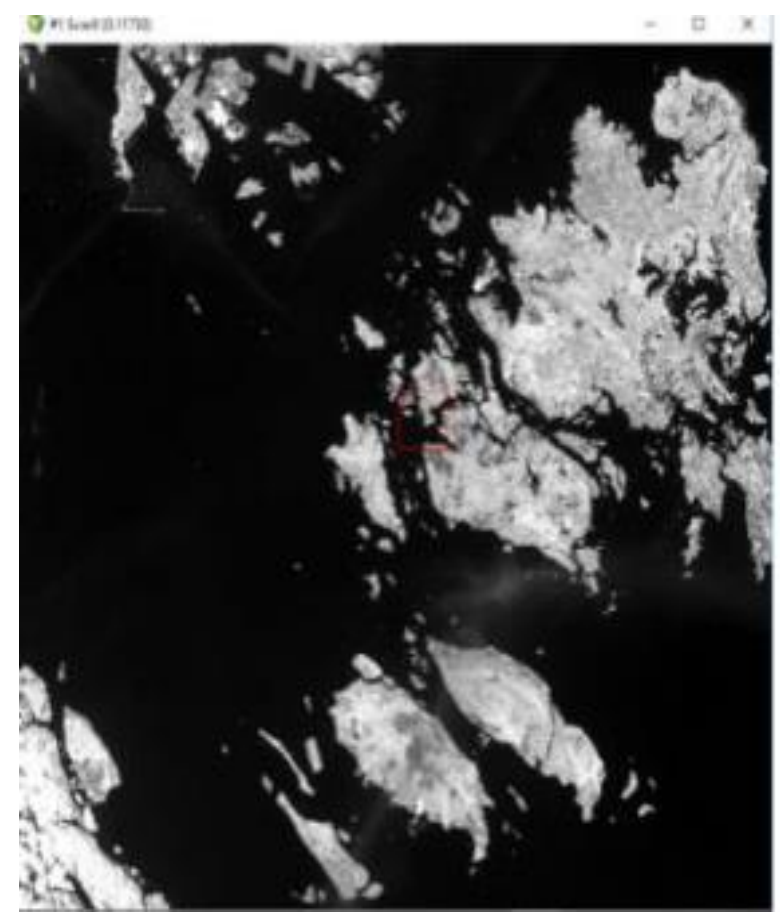

(a)
Klasifikasi multispektral pada penelitian ini menggunakan metode maximum likelihood. Klasifikasi ini bertujuan untuk mengindentifikasi dan mengklasifikasi antara objek hutan dan non hutan berdasarkan nilai spektral pada data citra. Langkah pertama yang dilakukan adalah menentukan daerah sampel sesuai dengan objekobjek yang diperlukan pada data citra yang digunakan menggunakan Region of Interest. Pada gambar 4 dapat dilihat klasifikasi dibagi menjadi 4 daerah sampel yaitu hutan, laut, lahan kosong dan pemukiman.

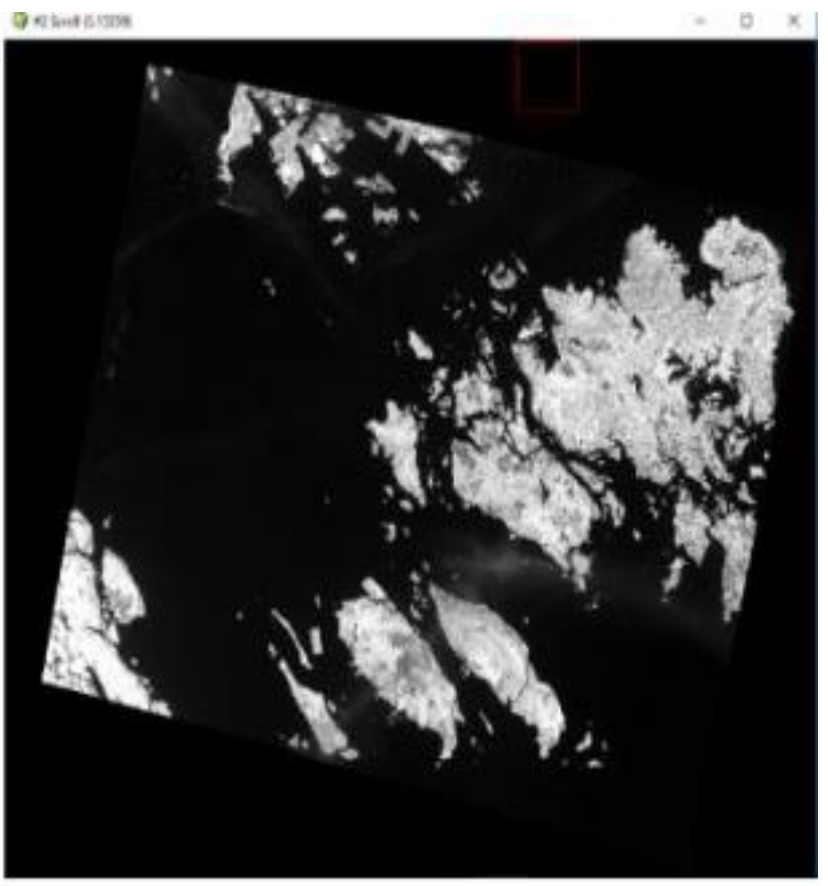

(b)

Gambar 3. Perbandingan Citra SPOT 5 sebelum (a) dan sesuadah (b)

\begin{tabular}{|c|c|c|c|c|}
\hline \multicolumn{3}{|c|}{$\theta$ \#1 ROI Tool } & - & \multirow[t]{2}{*}{$\square$} \\
\hline File & ROI_Type & Options & Telp & \\
\hline \multicolumn{2}{|c|}{ Window: Image } & Scroll & Zoom & Off \\
\hline & ROI Name & Color & Pixels & Polygd \\
\hline & HUTAN & Yellow & 28.430 & $0 / 0$ \\
\hline & LAUT & Blue & 5.948 & $0 / 0$ \\
\hline & LAHAN KOSONC & NC Maroon & 5.077 & $0 / 0$ \\
\hline - & PEMUKIMAN & Green & 5.022 & $0 / 0$ \\
\hline
\end{tabular}

(a)

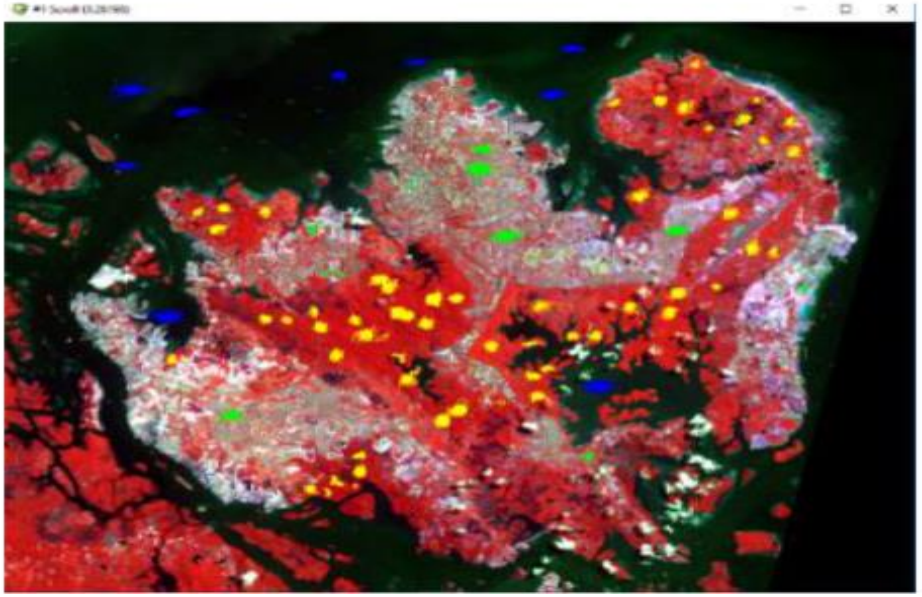

(b)

Gambar 4. Klasifikasi Multispektral berdasarkan Region of Interest 


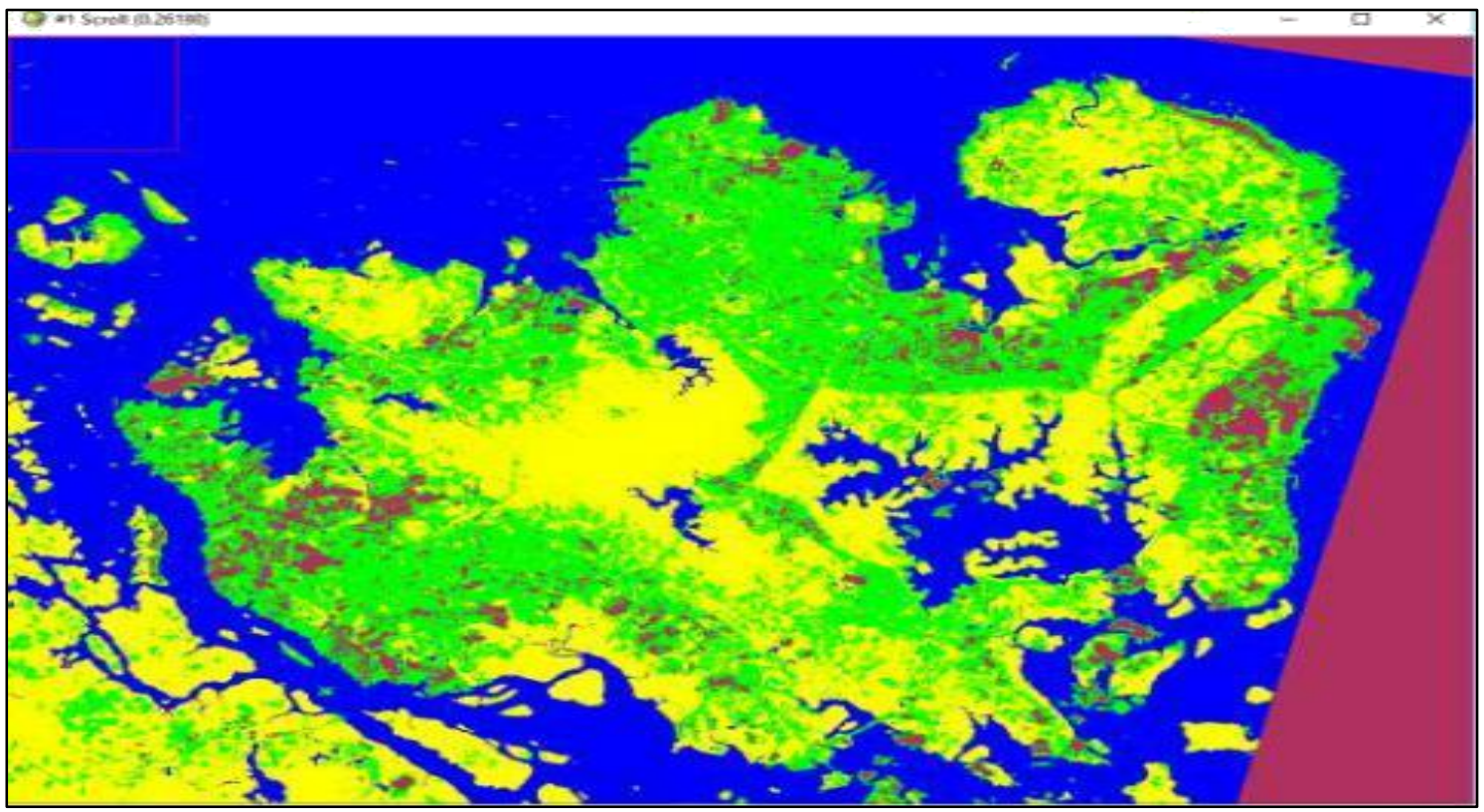

Gambar 5. Hasil klasifikasi multispektral dengan metode maximum likelihood

Transformasi Modified Soil-Adjusted Vegetation Index (MSAVI) dilakukan dengan proses band math pada perangkat lunak ENVI seperti yang ditampilkan pada Gambar 6. Lebih Berdasarkan formula yang digunakan maka nilai piksel dari data citra hasil transformasi MSAVI akan mengalami perubahan. Pada transformasi MSAVI, hanya 2 band yang digunakan untuk proses transformasi yaitu band merah (band 2 pada citra SPOT 5) dan infra merah dekat (band 3 pada citra

\section{SPOT 5).}

Data hasil pengukuran sampel digunakan dalam proses uji akurasi intepretasi dan pemodelan sampel. Seluruh hasil pengukuran sampel didata pada perangkat lunak pengolah data tabular Ms. Excel untuk proses pengolahan. Jumlah keseluruhan sampel kemudian dibagi dua dimana 22 data sampel digunkan untuk pemodelan sampel dan 15 data sampel digunakan untuk uji akurasi.

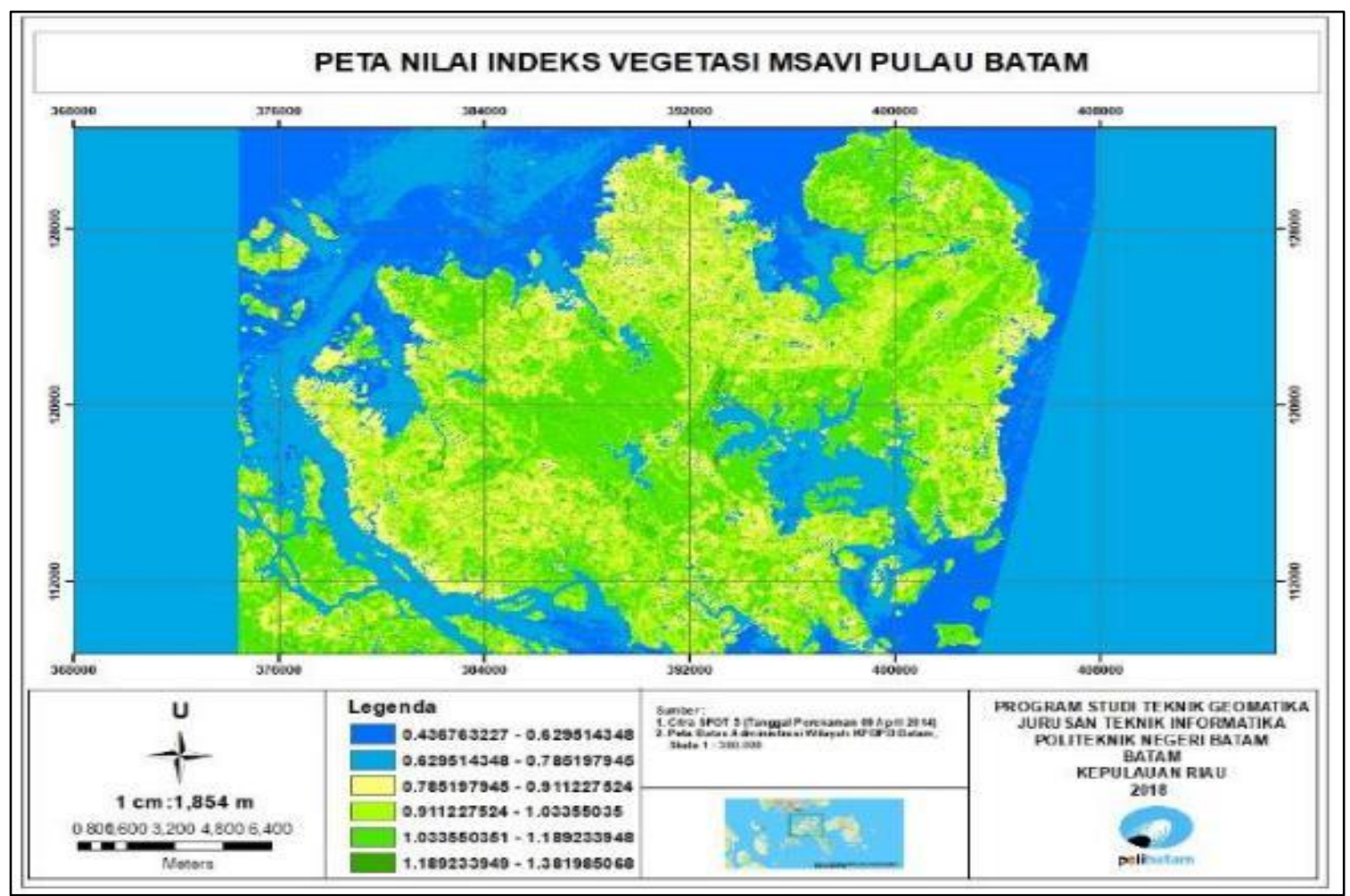

Gambar 6. Peta Nilai Indek MSAVI Pulau Batam 
Pemodelan sampel bertujuan untuk mengetahui seberapa besar hubungan regresi dan nilai kolerasi citra SPOT 5 sebagai data penginderaan jauh yg digunakan terhadap data lapangan yg telah diambil. Pada penelitian ini, terdapat 3 pemodelan yang dilakukan yaitu pemodelan nilai indeks vegetasi MSAVI terhadap diameter kanopi sampel, pemodelan diameter kanopi sampel terhadap besar DBH sampel dan pemodelan besar DBH terhadap jumlah karbon/ha. Hasil pemodelan pada penelitian ini ditampilkan grafik pada gambar 7, 8 dan 9 .

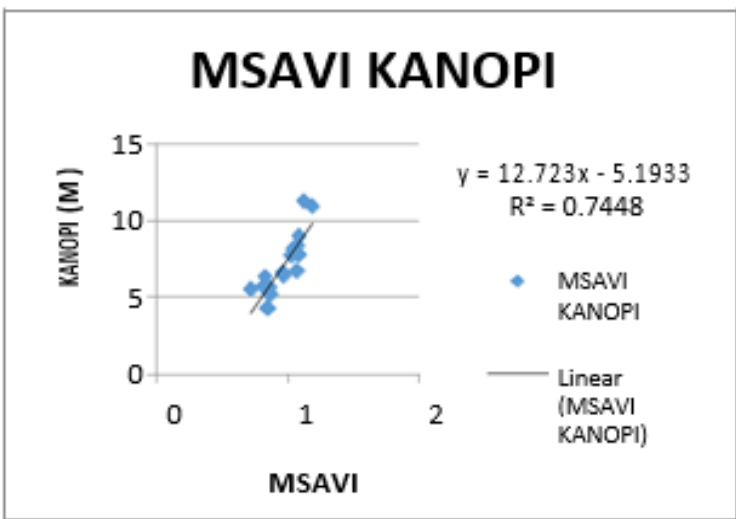

Gambar 7. Grafik Pemodelan nilai indeks transformasi MSAVI terhadap lebar kanopi

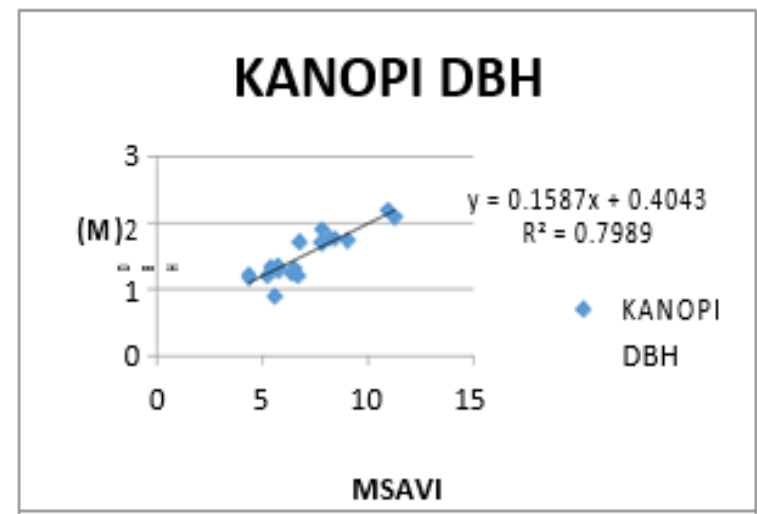

Gambar 8. Grafik Pemodelan lebar kanopi sampel terhadap DBH sampel

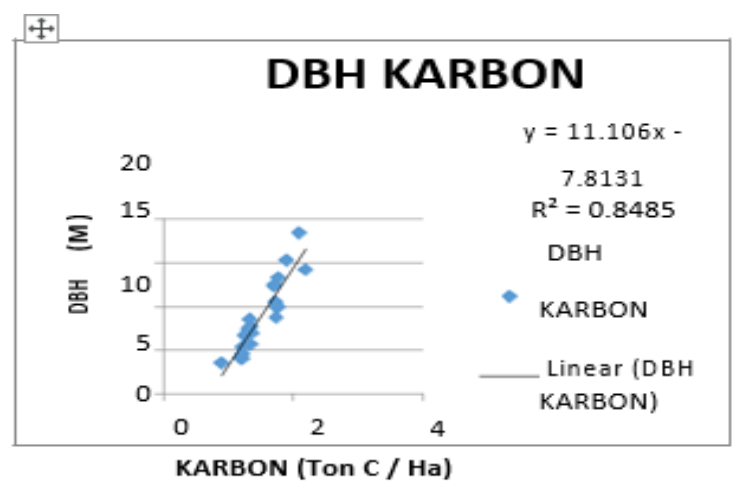

Gambar 9. Grafik Pemodelan DBH sampel terhadap estimasi jumlah karbon
Berdasakan hasil pemodelan diatas, nilai koefisien korelasi (R2) nilai indeks transformasi MSAVI terhadap lebar kanopi adalah sebesar 0,7448, nilai koefisien kerelasi lebar kanopi terhadap DBH sebesar 0,7989 dan nilai koefisisen korelasi lebar DBH terhadap estimasi jumlah karbon/ha sebesar 0,8485 . Interpretasi hubungan regresi berdasarkan koefisien korelasi nilai $\left(\mathrm{R}^{2}\right)$ (Tabel 3.4), untuk pemodelan nilai indeks transformasi MSAVI terhadap lebar kanopi dan pemodelan lebar kanopi terhadap besar DBH memiliki interpretasi hubungan kuat, sementara untuk pemodelan besar DBH terhadap estimasi jumlah karbon/ha memiliki hubungan interpretasi sangat kuat.

Uji akurasi diperlukan untuk mengetahui besar kesalahan (error) data penginderaan jauh yang digunakan pada penelitian dalam mempresentasikan estimasi jumlah karbon hutan Pulau Batam. Sebanyak 15 plot sampel digunakan dalam proses uji akurasi penelitian ini, dengan mencari akar dari kuadrat total nilai selisih antara data sebenarnya dengan data hasil estimasi seluruh sampel dibagi dengan total jumlah sampel uji akurasi. Perhitungan besar RMSE penelitian ini disajikan pada Tabel 1 dengan RMSE 4,731672893

\section{Tabel 1. Perhitungan Root Mean Square Error (RMSE)}

\begin{tabular}{cccc}
\hline MSAVI & $\begin{array}{c}\text { KARBON/ } \\
\text { ha (y) }\end{array}$ & $\begin{array}{c}\text { Karbon } \\
\text { Estimasi } \\
(\mathbf{y} \text { ') }\end{array}$ & $\mathbf{y}-\mathbf{y}$, \\
\hline 0,767609 & 0,313323383 & 0,711965554 & 0,15891558 \\
0,976209 & 5,317826824 & 3,028677154 & 2,28914967 \\
0,933285 & 4,063777269 & 2,55196321 & 1,511814059 \\
1,165688 & 9,8875167 & 5,133030928 & 4,754485772 \\
0,946966 & 4,500977511 & 2,703904396 & 1,797073115 \\
0,940821 & 8,565556482 & 2,635658026 & 5,929898456 \\
1,05877 & 4,031979187 & 3,94559962 & 0,086379567 \\
0,825841 & 14,20778563 & 1,358690146 & 12,84909548 \\
1,181573 & 10,58899882 & 5,309449738 & 5,279549082 \\
1,042902 & 10,003009 & 3,769369612 & 6,233639388 \\
1,05073 & 5,674179409 & 3,85630738 & 1,817872029 \\
0,922294 & 12,49811155 & 2,429897164 & 10,06821439 \\
0,887316 & 2,86638005 & 2,041431496 & 0,824948554 \\
1,054831 & 6,963812771 & 3,901853086 & 3,061959685 \\
0,886521 & 6,881355001 & 2,032602226 & 4,848752775 \\
\hline RMSE & & 4,848752775 &
\end{tabular}


Penyajian estimasi jumlah cadangan karbon dalam bentuk peta dilakukan melalui proses band math pada perangkat lunak Envi. Persamaan y $=a x$ $+\mathrm{b}$ yang didapatkan dari pemodelan nilai indeks vegetasi MSAVI terhadap diameter kanopi sampel, pemodelan diameter kanopi sampel terhadap besar DBH sampel dan pemodelan besar DBH terhadap jumlah karbon/ha digunakan sebagai formula dalam proses band math pada citra yang dilakukan secara sistematis.

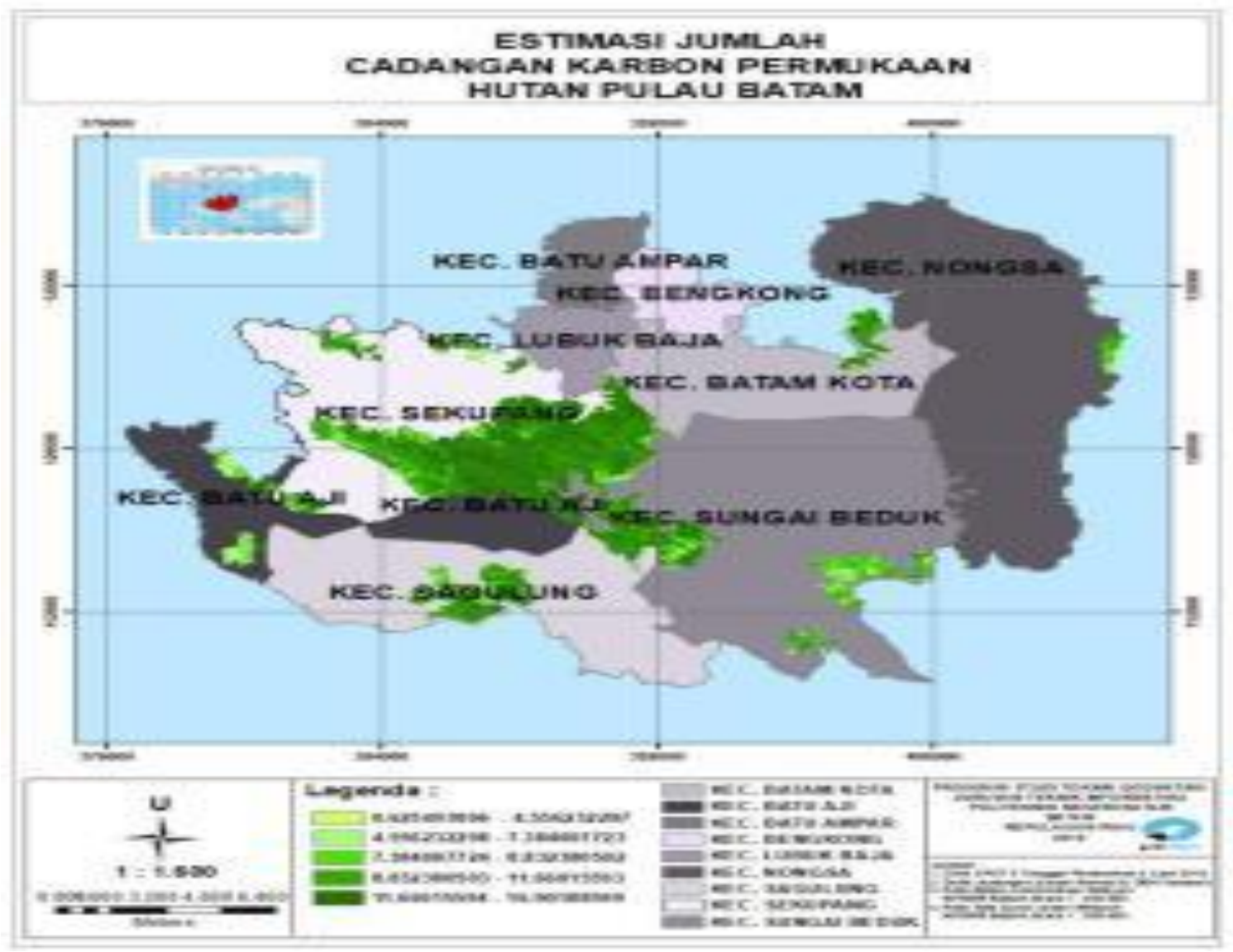

Gambar 7. Peta estimasi Jumlah jumlah cadangan karbon hutan Pulau Batam

Berdasarkan Gambar 7, kecamatan Batu Aji menyimpan cadangan karbon hutan permukaan sebesar 105,2990761709 Ton C/ha, Kecamata Batam Kota sebesar 21,5868778196 Ton C/ha, kecamatan Nongsa sebesar 8,2774192779, kecamatan sekupang 231,5348534922 Ton C/ha, kecamatan Sungai Beduk 168,4168649229 Ton C/ha dan kecamatan Sagulung 79,5397878654 Ton C/ha.

Sementara untuk wilayah kecamatan Batu Ampar dan Bengkong tidak menyimpan cadangan karbon permukaan karena daerah tersebut tidak memiliki wilayah hutan. Total estimasi jumlah karbon hutan Pulau Batam diketahui dengan mengakumulasikan seluruh nilai piksel citra karbon hutan Pulau Batam. Proses tersebut dilakukan menggunakan Spatial Analyst Tools pada perangkat lunak ArcMap.
Total estimasi jumlah karbon pada penelitian ini adalah sebesar 618,9944681939 Ton C/ha.

Tabel 2. Estimasi Cadangan Karbon Hutan Permukaan Pada Masing Masing Kecamatan di Pulau Batam

\begin{tabular}{llc}
\hline No. $\quad$ Kecamatan & $\begin{array}{c}\text { Estimasi Cadangan } \\
\text { Karbon Hutan } \\
\text { Permukaan } \\
\text { (Ton C/ha) }\end{array}$ \\
\hline 1 & Batu Aji & 105,2990761709 \\
2 & Batam Kota & 21,5868778196 \\
3 & Batu Ampar & - \\
4 & Bengkong & - \\
5 & Nongsa & 8,2774192779 \\
6 & Sekupang & 231,5348534922 \\
7 & Sungai Beduk & 168,4168649229 \\
8 & Sagulung & 79,5397878654 \\
\hline
\end{tabular}




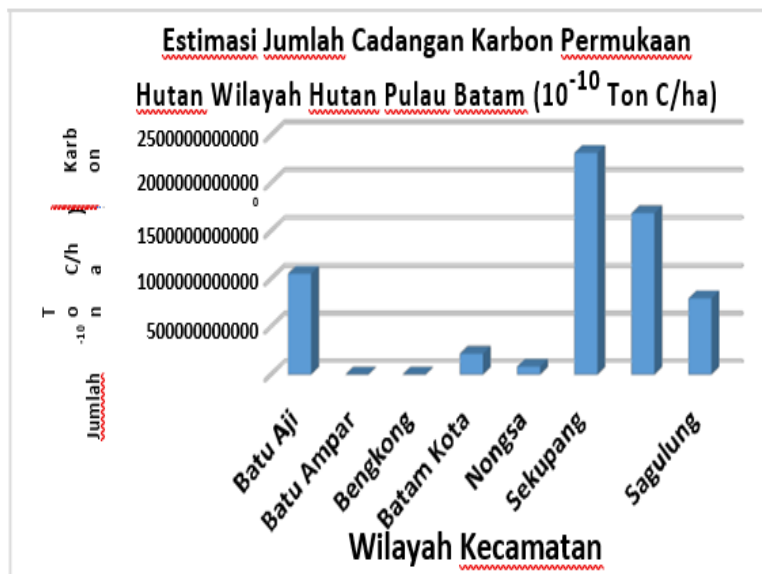

Grafik 4. Grafik estimasi cadangan karbon hutan permukaan pada masing masing kecamatan di Pulau Batam

\section{SIMPULAN}

Berdasarkan penelitan yang telah dilakukan, citra SPOT 5 sebagai data penginderaan jauh yang digunakan dalam estimasi jumlah cadangan karbon yang dapat ditampung oleh hutan Pulau Batam dapat menghasilkan data dan informasi yang cukup baik dan akurat. Estimasi total jumlah cadangan karbon permukaan yang dapat ditampung oleh hutan Pulau Batam adalah sebesar 618,9944681939 Ton $\mathrm{C} / \mathrm{ha}$ dengan tingkat kesalahan sebesar 4,731672893 . Wilayah kecamatan yang menyimpan cadangan karbon paling tinggi adalah kecamatan Sekupang dengan jumlah karbon sebesar 231,5348534922 Ton C/ha dan untuk wilayah yang menyimpan karbon paling rendah terdapat pada kecamatan Nongsa dengan jumlah karbon sebesar 8,2774192779 Ton C/ha, sementara untuk wilayah kecamatan Bengkong dan Batu Ampar tidak terdapat cadangan karbon permukaan hutan karena pada wilayah tersebut tidak terdapat daerah hutan.

\section{DAFTAR PUSTAKA}

Agus, F. (2004). Cadangan, Emisi dan Konservasi Karbon pada Lahan Gambut. Bunga Rampai Konservasi Tanah dan Air. Pengurus Pusat Masyarakat Konservasi Tanah dan Air Indonesia, 2007, 45-52.

Akbar, A. (2012). Persamaan Allometrik Untuk Menduga Kandungan Karbon Jenis Meranti (Shorea Teysmaniana) Di Hutan Alam Rawa Gambut Kalimantan Tengah. Jurnal Penelitian Sosial dan ekonomi Kehutanan, 9(1)

Anurogo, W., \& Murti, S. (2013). H. APLIKASI PENGINDERAAN JAUH UNTUK ESTIMASI PRODUKSI TANAMAN KARET (Hevea Brasiliensis) DI KOTA SALATIGA, JAWA TENGAH.

Brown, S. (1997). Estimating biomass and biomass change of tropical forests: a primer (Vol. 134). Food \& Agriculture Org.

Standar Nasional Indonesia (2011). Pengukuran dan penghitungan cadangan karbon-Pengukuran lapangan untuk penaksiran cadangan karbon hutan (ground based forest).

Samiaji, T. (2010). Upaya mengurangi CO2 di atmosfer. Berita Dirgantara, 10(3).

Wicaksono, P., Danoedoro, P., Hartono, \& Nehren, U. (2016). Mangrove biomass carbon stock mapping of the Karimunjawa Islands using multispectral remote sensing. International Journal of Remote Sensing, 37(1), 26-52.

Windarni, C., Setiawan, A., \& Rusita, R. (2018). Estimasi Karbon Tersimpan Pada Hutan Mangrove Di Desa Margasari Kecamatan Labuhan Maringgai Kabupaten Lampung Timur. Jurnal Sylva Lest 